\title{
Lannoitustavan vaikutus perunasadon kehittymiseen ja sadon laatuun
}

\author{
EERO VARIS \\ Hankkijan kasvinjalostuslaitos, Hyrylä \\ ILMO LANNETTA \\ Maatalouskoneiden tutkimuslaitos, Rukkila
}

\section{Effects of fertilization rate and application method on the yield development and quality of potatoes}

\author{
Eero VARIS \\ Plant Breeding Institute of Hankkija, Hyrylä, Finland \\ ILMO LANNETTA \\ Finnish Research Institute of Agricultural Engineering, Rukkila, Finland
}

\begin{abstract}
Drilling and placing of fertilizer were compared with broadcasting in trials carried out at the Plant Breeding Institute of Hankkija and at the Finnish Research Institute of Agricultural Engineering from 1968-71. Two rates of a commercially compounded fertilizer (N-P-K = 7-11-12) were used.

Doubling the fertilization rate increased the tuber yield by 12 per cent. Drilling produced a yield increase of 6 per cent, placing of 11 per cent.

The fertilization rate strongly affected the yield increase of a given application method. At the lower fertilization rate, the yield increase from drilling was 7 per cent, from placing, 18 per cent. At the higher fertilization rate, the yield increases were 5 per cent in both cases.

The starch content was decreased by 0.5 per cent by the increased fertilization rate. Application methods had no significant effects upon the starch content.

Starch yields were in accordance with tuber yields.

The proportion of large tubers was increased by the heavier fertilization rate. The application method had no clear effect on the tuber size distribution. Yearly variations were, however, great.

A doubled fertilization rate increased slightly the scabbiness of the crop and the percentage of tubers infected with black scurf. Application methods had no effect upon the scabbiness or black scurf.

Growth analysis showed a clear positive effect of drilling and placing on the vegetative growth of the potato, an even greater effect than that caused by a doubled fertilization rate. At the higher fertilization rate, growth was retarded somewhat by placing.

Stem number per hill varied yearly $(4.3-5.3)$. Treatments included caused few variations. At the higher fertilization rate, drilling increased the stem number.

Tuber number per hill varied greatly from year to year $(8.6-13.5)$. It was clearly increased by drilling and placing. This increase, however, was not so noticeable by the end of the growing period.
\end{abstract}


Lannoitteiden multaaminen tai sijoitus viljan viljelyssä yleistyi Suomessa 1960-luvun lopulla niiden lupaavien koetulosten ja käytännön kokemusten perusteella, joita menetelmistä saatiin (Elonen ym. 1967, NiEminen ym. 1967, Salonen 1968, Pessi ym. 1970). Menetelmiä kokeiltiin aluksi pääasiassa kevätviljoilla, joilla myös tulokset olivat hyvät. Rivimultainten yleistyessä käytännössä näytti kuitenkin tarpeelliselta selvittää myös mm. perunan suhtautumista lannoitteiden multaukseen ja sijoitukseen, koska ulkomailta saatiin alustavia lupaavia tietoja (BAERUG 1971) ja koska myös omat alustavat kokemukset havaintokentiltä vuosina $1966-67$ osoittivat selvää kasvun nopeutumista alkukesästä. Asiaa selvittäviä kokeita järjestettiin vuosina 1968-72 Hankkijan kasvinjalostuslaitoksen Anttilan koetilalla yhteistoiminnassa Maatalouskoneiden Tutkimuslaitoksen kanssa. Neljään kokeeseen liitettiin myös varhaisnostot kasvututkimuksineen ja kemiallisine analyyseineen, jotta olisi voitu tarkemmin selvittää mahdolliset kasvurytmin muutokset ja ravinteiden saannin erot.

\section{Koeaineisto ja sen käsittely}

Kokeita järjestettiin vuosien 1968-72 aikana kaikkiaan 8, näistä 5 Hankkijan kasvinjalostuslaitoksen Anttilan koetilalla ja 3 Maatalouskoneiden Tutkimuslaitoksen koetiloilla. Maalaji oli Anttilan 4 kokeessa aitosavipohjaista multamaata, 1 kokeessa hiesunsekaista hietaa (vrt. VARIs 1973), Maatalouskoneiden Tutkimuslaitoksella hietaa.

Koejäsenet olivat:

\section{Lannoitemäärät}

A. $650 \mathrm{~kg} / \mathrm{ha} \mathrm{Yklv}(33-46 \mathrm{~N}, 34-72 \mathrm{P}, 78-81 \mathrm{~K})$

B. $1300 \mathrm{~kg} / \mathrm{ha} \mathrm{Yklv}(65-91 \mathrm{~N}, 69-143 \mathrm{P}, 156-160 \mathrm{~K})$

\section{Lannoitustavat}

1. Pintalannoitus

2. Rivimultaus, mullattu $16.5 \mathrm{~cm}: n$ rivivälein

3. Sijoituslannoitus, sijoitettu siemenmukulan molemmin puolin n. $10 \mathrm{~cm}: \mathrm{n}$ etäisyydelle mukulasta.

Lannoitteena käytettiin vuosittain kaupassa olevaa kloorivapaata Y-lannosta.

Lannoitteiden sijoittamiseksi 2-riviin Piirroksen 1 osoittamalla tavalla Maatalouskoneiden tutkimuslaitoksella rakennettiin yhdistelmäkone, joka sijoitti lannoitteet ja istutti perunat. Pinta- ja rivilannoitukseen käytettiin rivimultainta. Perunat istutettiin aina yhdistelmäkoneen istutusautomaatilla.

Koeruudut olivat 4-rivisiä, à 25 mukulaa. Kaksi keskimmäistä riviä korjattiin syysnostoissa. Kerranteita oli 4, lajike Rekord. Varhaisnostoja varten kylvettiin Anttilaan multamaan kokeen yhteyteen ylimääräisiä ruutuja, joista korjattiin 4 nostoaikana $2 \times 1$-riviset ruudut. Nostoajat olivat keskimäärin: 27. 07., 12. 08., 25. 08. ja 17.09. 

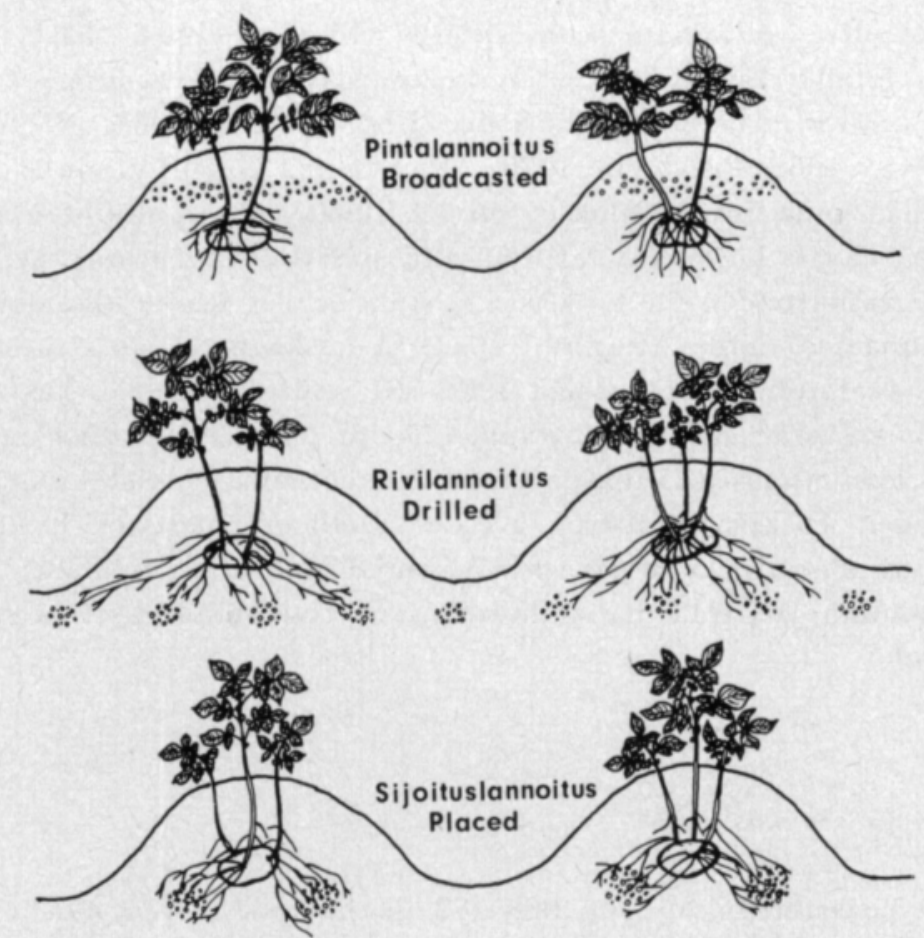

Piirros 1. Kaaviokuva selostettavassa kokeessa käytetyistä lannoitteiden kylvötavoista. Figure 1. Scheme of fertilizer application methods used in the trial series reported here.

Seuraavat havainnot esitetään:

Varhaisnostot

Lehdistön paino $\mathrm{g} / \mathrm{yksilö.}$

Varsia kpl/yksilö.

Mukulasato g/yksilö.

Mukuloita kpl/yksilö.

Mukuloiden kokojakautuma (\%): alle $40 \mathrm{~mm}, 40-55 \mathrm{~mm}$ ja yli $55 \mathrm{~mm}$.

Tärkkelys-\% (Hals \& Bucholzin mukaan).

Varhaisnostoista otettiin myős lehdistö- ja mukulanåytteet kemiallisia analyyseja varten. Tulokset esitetään myöhemmässä julkaisussa.

\section{Syysnosto}

Mukulasato $\operatorname{tn} /$ ha.

Tärkkelys-\% (Hals \& Buchholz).

Tärkkelyssato $\mathrm{kg} / \mathrm{ha}$.

Sadon kokojakautuma (\%), alle $40 \mathrm{~mm}, 40-55 \mathrm{~mm}$ ja yli $55 \mathrm{~mm}$.

Sadon rupisuus $0-10 \quad(0=$ terve, $10=$ täysin rupinen).

Seittisiä mukuloita \%. 
Tulosten tilastollisessa käsittelyssä käytettiin varianssianalyyssejä, jotka laskettiin Keskusosuusliike Hankkijan ATK-osastolla. Tulosten tilastollinen merkitsevyys on esitetty tavalliseen tapaan (Taulukot 1 ja 2).

Taulukko 1. Varianssianalyysi lannoitustavan vaikutuksesta perunasadon kehittymiseen. Table 1. Analysis of variance of the effects of the fertilizer application method on the development of potato yield.

\begin{tabular}{|c|c|c|c|c|c|}
\hline $\begin{array}{l}\text { Tekijä } \\
\text { Factor }\end{array}$ & 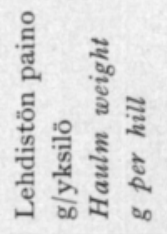 & 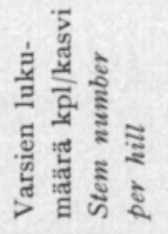 & 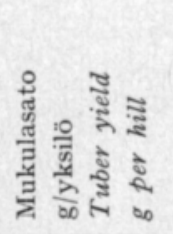 & 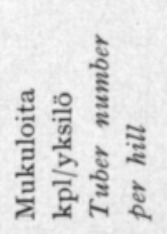 & 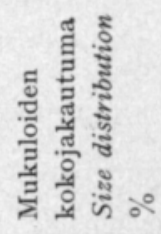 \\
\hline A. Koe - Trial ......... & $* * *$ & $* * *$ & $* * *$ & $* * *$ & $* * *$ \\
\hline $\begin{array}{l}\text { B. Lannoitustaso- } \\
\text { Fertilization level . }\end{array}$ & $* * *$ & ns & ns & $(*)$ & ns \\
\hline $\begin{array}{l}\text { C. Lannoitustapa - } \\
\text { Application method }\end{array}$ & $* *$ & ns & $(*)$ & $* * *$ & ns \\
\hline $\begin{array}{l}\text { D. Nostoaika - } \\
\text { Lifting time .......... }\end{array}$ & $* * *$ & ** & $* * *$ & $* * *$ & $* * *$ \\
\hline AB & ns & * & ** & ns & $* * *$ \\
\hline AC $\ldots \ldots \ldots \ldots \ldots \ldots \ldots \ldots$ & $* * *$ & ns & ns & ns & $* * *$ \\
\hline 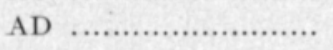 & $* * *$ & $(*)$ & $* * *$ & $* * *$ & $* * *$ \\
\hline BC & $* *$ & $*$ & * & ns & $*$ \\
\hline BD & ns & ns & ns & ns & ** \\
\hline CD & ns & ns & ns & * & ns \\
\hline ABC & ** & ns & ns & * & $* * *$ \\
\hline ABD $\ldots \ldots \ldots \ldots$ & $* * *$ & ns & ns & ns & *** \\
\hline ACD & ** & ns & ns & * & $* * *$ \\
\hline BCD & $(*)$ & * & ns & ns & $* * *$ \\
\hline
\end{tabular}

Lehdistön paino

Lisätty lannoitus aiheutti lehdistön rehevämmän kasvun (keskimäärin 270 ja $306 \mathrm{~g})$. Rivimultaus ja sijoitus vaikuttivat samoin lehdistön kasvua rehevoittävästi $(269,292$ ja $302 \mathrm{~g})$. Piirroksesta 2 näkyvät yhdysvaikutukset BC ja BCD. Pientä lannoitemäärää käytettäessä sijoituslannoitus aiheutti rehevimmän varsiston kasvun. Sen sijaan suurempaa lannoitemäärää käytettäessä sijoituslannoituksessa varsiston kasvu hidastui syyskesällä verrattaessa rivimultaukseen. Vuotuista vaihtelua oli runsaasti ( $A, A C, A D, A B C, A B D$, $\mathrm{ACD})$. 
Taulukko 2. Varianssianalyysi lannoitustavan vaikutuksesta perunasatoon ja sen laatuun. Table 2. Analysis of variance of the effects of the fertilizer application method on the yield and quality of potatoes.

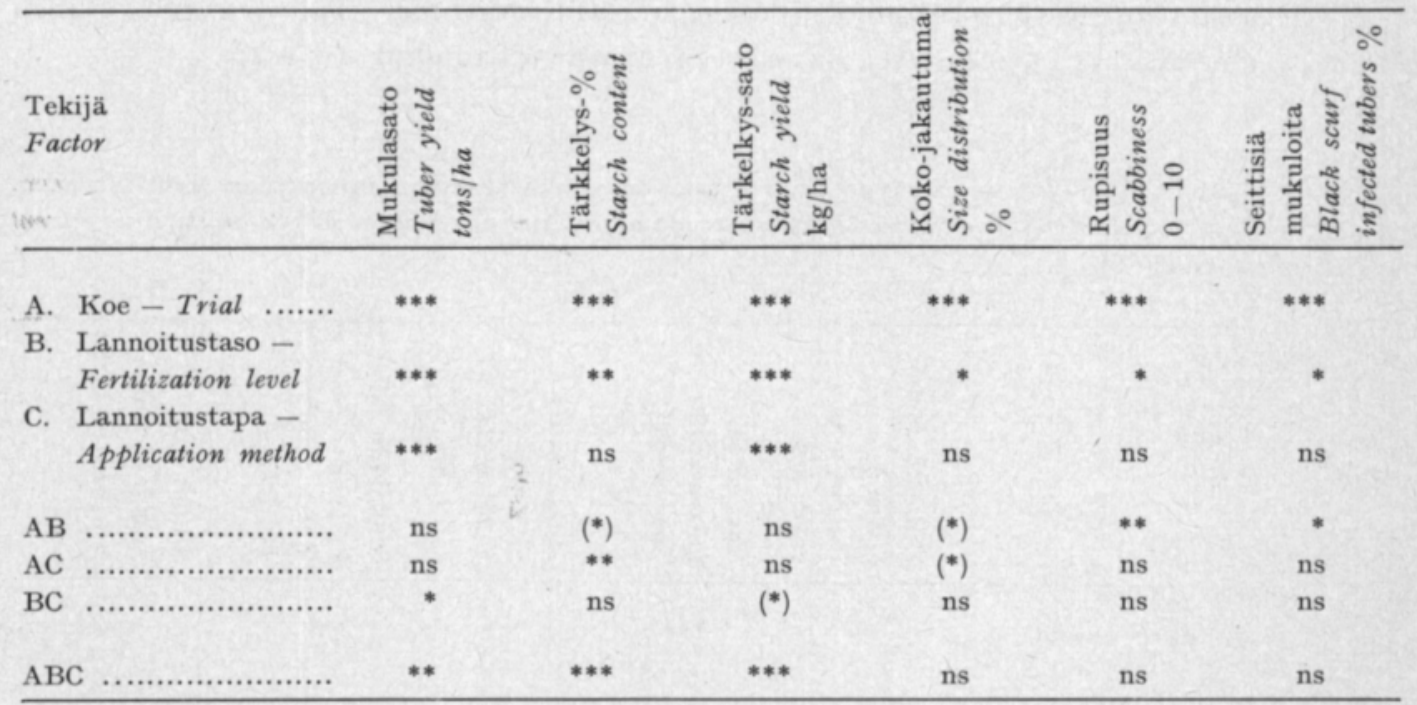

\section{Varsien lukumäärä}

Varsien lukumäärä yksilöä kohti vaihteli vuosittain $(4.3-5.3 \mathrm{kpl})$. Se muuttui myös hiukan kasvukauden kuluessa (4.8-4.9-4.8-4.5). Lannoituksen määrä ja tapa vaikuttivat myös jossain määrin varsien lukumäärään (Taulukko 3).

Taulukko 3. Lannoituksen määrän ja tavan vaikutus perunan varsien lukumäärään.

Table 3. The effects of fertilizer application level and method on the stem number of potatoes.

\begin{tabular}{|c|c|c|c|}
\hline $\begin{array}{l}\text { Lannoitustapa } \\
\text { Application method }\end{array}$ & $\begin{array}{r}650 \\
Y k l v\end{array}$ & $\begin{array}{l}1300 \\
\text { Yklv }\end{array}$ & $\begin{array}{l}\text { Keskim. } \\
\text { Average }\end{array}$ \\
\hline Pinta - Broadcasted ............................. & 4.7 & 4.6 & 4.7 \\
\hline Rivi - Drilled ................................... & 4.6 & 5.0 & 4.8 \\
\hline 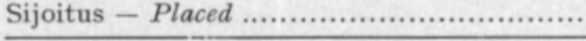 & 4.8 & 4.8 & 4.8 \\
\hline Keskim. - Average ................................ & 4.7 & 4.8 & \\
\hline PME - L.S.D. $(5 \%)$ & $\begin{array}{l}\text { Lannoitustasot } \\
\text { Fertilization levels } \\
\text { Lannoitustavat } \\
\text { Application methods } \\
\text { BC }\end{array}$ & $\begin{array}{l}\text { (B) } \mathrm{ns} \\
\text { (C) } \mathrm{ns} \\
0.3\end{array}$ & \\
\hline
\end{tabular}

Selvä merkittävä ero oli rivilannoituksessa, missä lannoituksen lisääminen pystyi lisäämään myös versojen lukumäärää. Yhdysvaikutus BCD osoitti, 


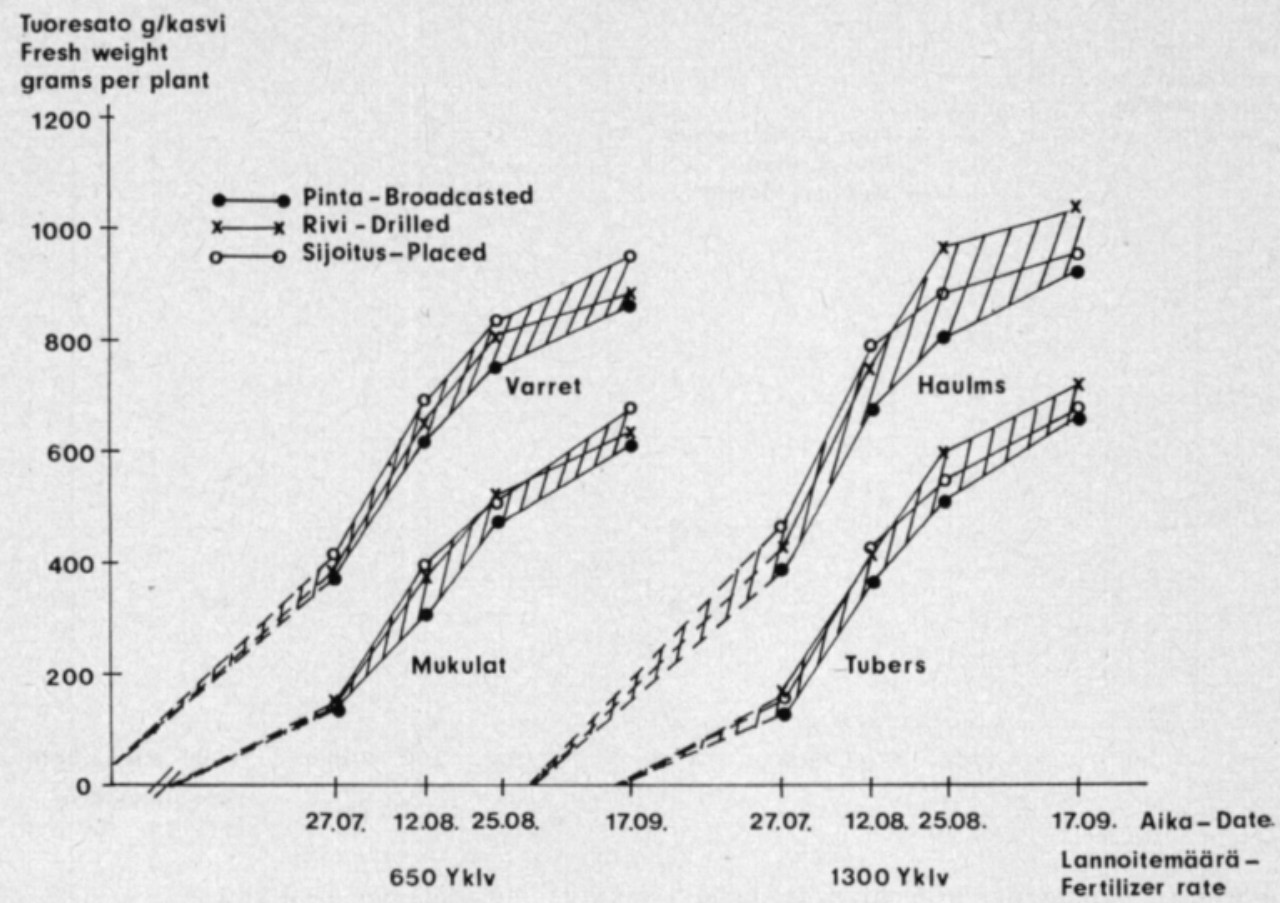

Piirros 2. Lannoituksen määrän ja tavan vaikutus perunan kasvuun.

Figure 2. The effects of fertilization rate and application method on the growth of the potato.

että versojen lukumäärä laski kasvukauden lopulla eniten rivilannoituksen pienellä lannoitemäärällä ja sijoituslannoituksen suurella lannoitemäärällä (vrt. Piirros 2). Vuotuista vaihtelua todettiin (A, AB, AD).

\section{Mukulasato}

Mukulasadon kehittymisessä oli samoja piirteitä kuin lehdistön painon kehityksessä (Piirros 2). Lannoitustasojen välillä ei keskimäärin ollut merkitsevää eroa, joskin suunta oli suuremman lannoitemäärän eduksi $(426,445 \mathrm{~g}$ ) kasvi). Ero näytti suurenevan syksyä kohti, ei tosin merkitsevästi. Lannoitustavoista rivimultaus ja sijoitus olivat keskimäärin yhtä hyvät $(412,446$, $448 \mathrm{~g} /$ kasvi), mutta lannoitemäärä vaikutti näiden paremmuusjärjestykseen (BC). Vuotuista vaihtelua esiintyi (A, AB, AD).

\section{Mukuloiden lukumäärä}

Mulukoiden lukumäärä kasvia kohti vaihteli vuosittain $(8.6-13.5 \mathrm{kpl} /$ kasvi) ja muuttui kasvukauden kuluessa (11.1-11.8-10.5-9.6 kpl/kasvi).

Lannoituksen määrä vaikutti lievästi merkitsevästi mukuloiden lukumäärään $(10.6,10.9 \mathrm{kpl} / \mathrm{kasvi})$, lannoitustavan vaikutus oli selvästi merkitsevä $(9.9,11.0,11.3 \mathrm{kpl} / \mathrm{kasvi})$. Mukuloiden lukumäärä muuttui kasvukauden kuluessa eri tavalla riippuen lannoitustavasta (CD, Piirros 3). Sijoituslannoituk- 


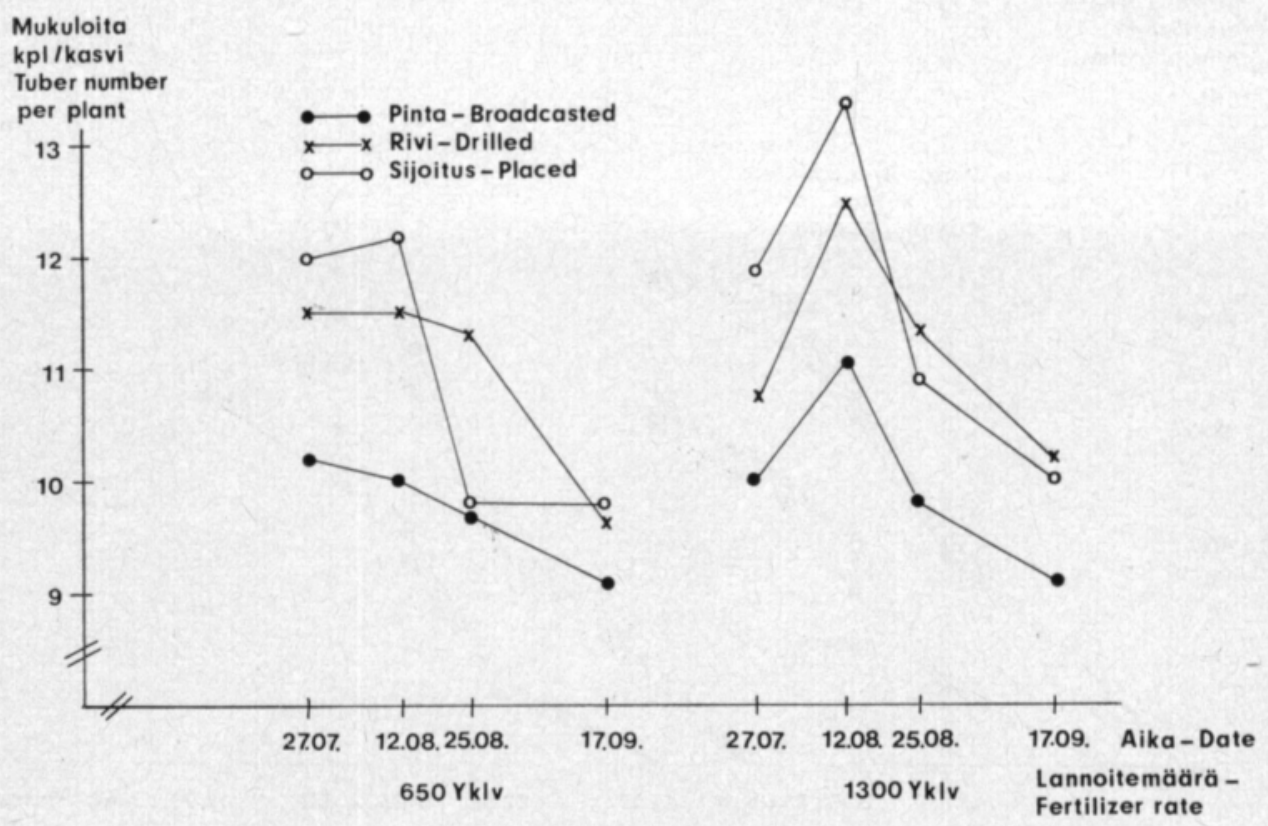

Piirros 3. Lannoituksen määrän ja tavan vaikutus mukulaluvun kehitykseen.

Figure 3. The effects of fertilization rate and application method on the development of tuber number.

sella saatiin kasvukauden alussa kehittymään sangen suuri mukulamäärä, joka kuitenkin syyskesällä jyrkästi väheni osan mukuloista kuihtuessa. Rivilannoituksen mukulamäärä oli myös hyvä syyskesään saakka, kunnes sekin syksyllä laski selvästi. Syksyllä mukulamäärien erot olivat suhteellisen pienet.

Mukuloiden kokojakautuma

Lannoituksen määrä ja tapa eivät keskimäärin vaikuttaneet kokojakautumaan (B, C), mutta sen sijaan niiden yhdysvaikutus (BC) oli merkitsevä (Piirros 4).

Ison lannoitemäärän koejäsenissä oli kasvukauden loppupuolella selviä eroja varsinkin isojen mukuloiden määrissä (BCD). Rivilannoituksen sadon nousu syyskesällä näytti muita enemmän johtuneen mukulakoon suurenemisesta. Pintalannoituksessa suurenivat sekä pienten että isojen mukuloiden määrät, sijoituslannoituksessa taas keskikokoisten määrä oli selvästi suurempi kuin muita lannoitustapoja käytettäessä.

\section{Syysnosto}

Varsinais:ssa syysnostoissa oli mukana kaikkiaan 8 koetta, joten edellä es.tetyn 4 kasvututkimuksen tulokset eivät suoraan ole rinnastettavissa seuraavassa esitettäviin tu'oksiin. 


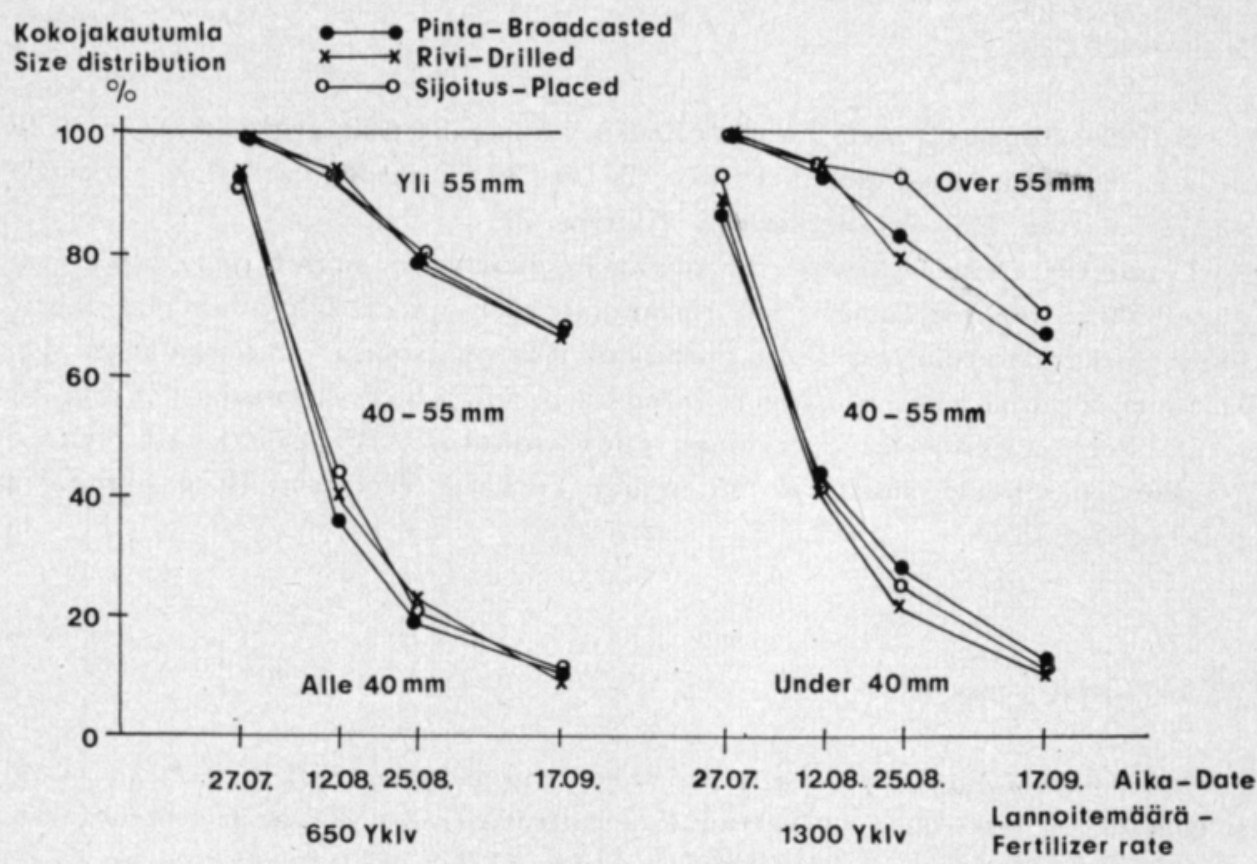

Piirros 4. Lannoituksen määrän ja tavan vaikutus mukulakoon kehittymiseen.

Figure 4. The effects of fertilization rate and applicatien method on the development of tuber size.

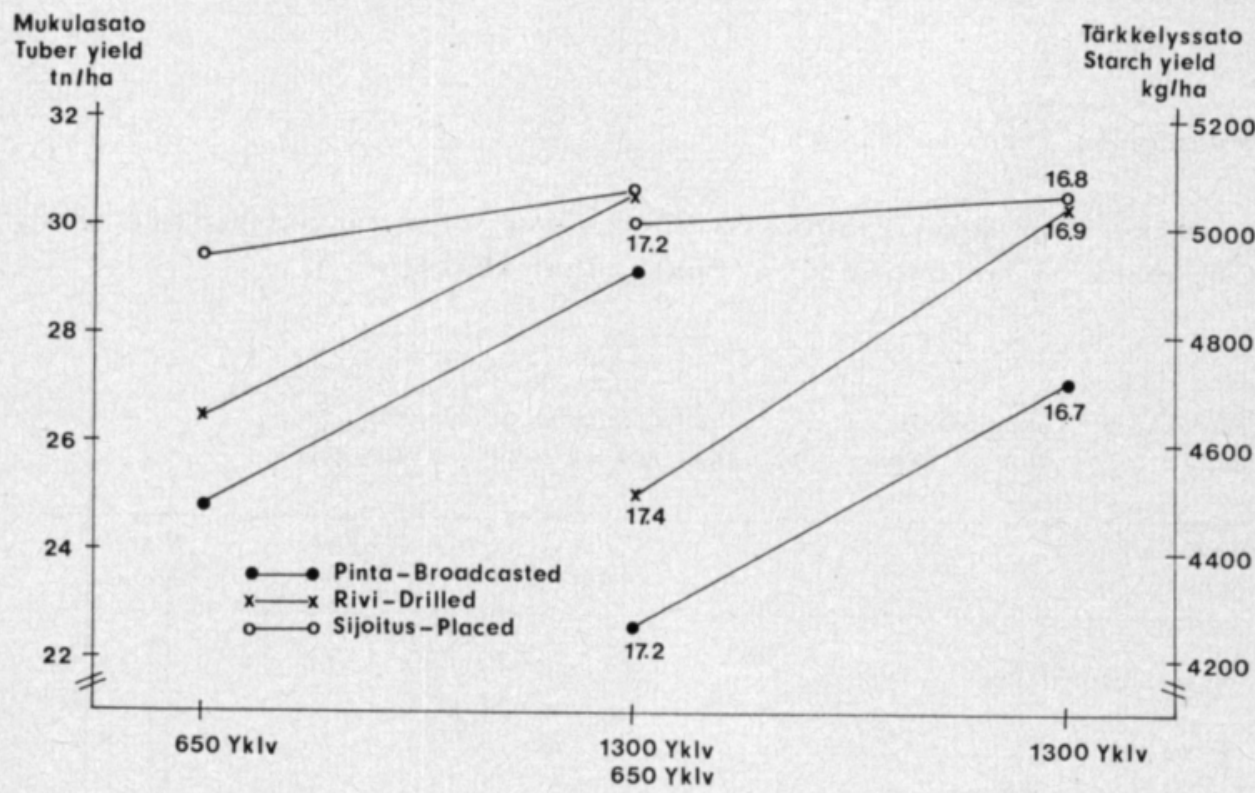

Piirros 5. Lannoituksen määrän ja tavan vaikutus mukula- ja tärkkelyssatoon.

Figure 5. The effects of fertilization rate and application method on tuber and starch yield. 


\section{Mukulasato}

Mukulasadossa oli merkitsevä ero sekä lannoituksen määrien (26.92 ja 30.12 tn/ha) että lannoitustapojen välillä $(26.99,28.51$ ja $30.05 \mathrm{tn} / \mathrm{ha})$. Lisäksi yhdysvaikutus BC oli merkitsevä (Piirros 5).

Lannoitustapojen väliset erot olivat huomattavan suuret pienempää lannoitemäärää käytettäessä. Sijoituslannoituksen pieni lannoitemäärä antoi jopa paremman tuloksen kuin pintalannoituksen isompi lannoitemäärä. Eri kokeiden antama tulos oli sangen yhtenäinen, sillä yhdysvaikutukset $\mathrm{AB}$ ja $\mathrm{AC}$ eivät olleet merkitseviä. Sen sijaan yhdysvaikutus $\mathrm{ABC}$ osoitti vaihtelua eri koejäsenien sadossa, mutta ei kuitenkaan koskaan oleellisesti BC:n suunnasta poikkeavasti.

\section{Tärkkelyspitoisuus}

Lannoituksen lisääminen alensi tärkkelyspitoisuutta (17.2 ja $16.8 \%$ ). Lannoitustapa ei sen sijaan vaikuttanut merkitsevästi, vaikka pieni ero pintalannoituksen vahingoksi oli havaittavissa $(16.9,17.2$ ja $17.0 \%$, Piirros 5).

\section{Tärkkelyssato}

Tärkkelyssato määräytyi pääasiassa mukulasadon mukaan (Piirros 5). Rivimultaus osoittautui suhteellisesti hiukan muita edullisemmaksi lievästi korkeampien tärkkelyspitoisuuksien ansiosta.

\section{Mukuloiden kokojakautuma}

Mukuloiden kokojakautumassa oli merkitsevä ero lannoitemäärien välillä (B), mutta ei lannoitustapojen välillä (Taulukko 4).

Taulukko 4. Lannoituksen määrăn vaikutus mukulakokoon.

Table 4. The effect of fertilizer application rate on tuber size distribution.

\begin{tabular}{|c|c|c|c|}
\hline $\begin{array}{l}\text { Mukulakoko } \\
\text { Tuber size }\end{array}$ & $\begin{array}{r}650 \\
\text { Yklv }\end{array}$ & $\begin{array}{l}1300 \\
Y k l v\end{array}$ & $\begin{array}{l}\text { Keskim. } \\
\text { Average }\end{array}$ \\
\hline Alle - Under $40 \mathrm{~mm}$............................ & 11 & 10 & 11 \\
\hline 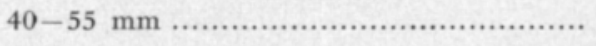 & 59 & 57 & 58 \\
\hline 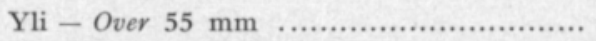 & 30 & 33 & 31 \\
\hline
\end{tabular}


Lannoituksen lisääminen aiheutti suurten mukuloiden määrän kasvamisen keskikokoisten kustannuksella. Lannoitustavan vaikutus mukulakokoon oli vuosittain vaihteleva $(\mathrm{AC})$, mutta keskimäärin mukuloiden kokojakautumissa ei ollut eroja.

\section{Mukuloiden taudit}

Lannoituksen lisääminen aiheutti lievän rupisuuden nousun. Samoin seittisten mukuloiden määrä kasvoi lievästi. Lannoitustapa ei aiheuttanut eroja (Taulukko 5).

Taulukko 5. Lannoituksen määrän ja tavan vaikutus mukuloiden tauteihin.

Table 5. The effects of fertilizer application level and method on tuber diseases.

\begin{tabular}{|c|c|c|c|c|c|c|}
\hline \multirow{2}{*}{$\begin{array}{l}\text { Lannoitustapa } \\
\text { Application method }\end{array}$} & \multicolumn{3}{|c|}{$\begin{array}{l}\text { Rupisuus } \\
\text { Scabbiness }\end{array}$} & \multicolumn{3}{|c|}{$\begin{array}{l}\text { Seittisiä mukuloita } \\
\text { Black scurf infected }\end{array}$} \\
\hline & $\begin{array}{c}650 \\
Y k l v\end{array}$ & $\begin{array}{l}1300 \\
\text { Yklv }\end{array}$ & $\begin{array}{l}\text { Keskim. } \\
\text { Average }\end{array}$ & $\begin{array}{c}650 \\
\text { Yklv }\end{array}$ & $\begin{array}{l}1300 \\
\text { Yklv }\end{array}$ & $\begin{array}{l}\text { Keskim. } \\
\text { Average }\end{array}$ \\
\hline Pinta - Broadcasted .......... & 10 & 11 & 11 & 12 & 14 & 13 \\
\hline Rivi - Drilled ................... & 9 & 12 & 10 & 11 & 16 & 13 \\
\hline Sijoitus - Placed .................. & 10 & 13 & 11 & 10 & 12 & 11 \\
\hline Keskim. - Average ..... & 10 & 12 & & 11 & 14 & \\
\hline
\end{tabular}

\section{Tulosten tarkastelua}

Lannoitteiden multaaminen rivimultaimella tai sijoituslaitteella näyttää näiden koetulosten mukaan antavan perunalla huomattavia, 5-18\%:n, sadonlisäyksiä. Sadon laadun muutokset ovat pieniä. Samanlaisiin tuloksiin on tultu muissakin vastaavissa tutkimuksissa (LARPES 1968, BATEY ja Boyd 1969, Baerug 1971, Laughlin 1971, Pettersson ja Wikström 1972, Hempler 1973).

Lannoitteiden erilaisia sijoitustapoja ovat muutamat tutkijat selvittäneet tarkemmin (BAtey ja Boyd 1969, Baerug 1971, Laughlin 1971). Tulokset ovat olleet vaihtelevia riippuen käytetyistä lannoitemääristä ja kasvuoloista. Yleissuunta näissä tutkimuksissa näyttää kuitenkin olevan, että mitä pienempää lannoitemäärää käytetään, sitä lähemmäksi siemenmukulaa lannoite voidaan sijoittaa tai sitä kapeampaa nauhaa voidaan käyttää. Sen sijaan jos suuri lannoitemäärä sijoitetaan lähelle siemenmukulaa kapeaksi nauhaksi, on voitu todeta kasvuhäiriöitä ja juurien polttovikoja sitä herkemmin, mitä kuivempi kasvukausi on.

Tämä sama ilmiö näkyy myös tässä esitetyissä tuloksissa. Pientä lannoitemäärää käytettäessä saatiin sijoittamalla huomattavasti parempi tulos kuin rivimultaamalla, mutta suurempaa lannoitemäärää käytettäessä ero tasoittui, 
koska sijoituslannoituksella sato ei juuri lainkaan noussut lannoitemäärää lisättäessä. Kasvututkimuksen tuloksista käy myös selville, että kasvien tuorepaino kasvoi iso lannoitemäärä sijoitettaessa syyskesällä hitaammin kuin rivimullattaessa, mikä on merkki häiriintyneestä lisäkasvusta. Samalla tavalla mukulamäärien kehitys kasvukauden aikana osoitti, miten sijoituslannoitus johti alkukesällä sangen runsaaseen mukulamäärään. Tämä aleni kuitenkin kasvukauden loppupuolella huomattavasti todennäköisesti kasvun häiriintymisestä johtuen. Kasvun häiriintymisen syiden tietäminen olisi sinänsä tärkeää, sillä sijoituslannoituksen aikaansaama lupaava mukulamäärän kehitys alkukesästä antoi itse asiassa mahdollisuuden sangen suuren sadon kehittymiseen: mukulamäärien ero pintalannoituksen ja sijoituksen välillä oli nimittäin suurimmillaan $22 \%$, mutta syksyllä vain $6 \%$.

Nämä koetulokset osoittivat muiden vastaavien tulosten tapaan, että käyttämällä lannoitteiden multausta päästään samaan satotasoon huomattavasti pienemmällä lannoitemäärällä kuin pintalannoituksessa. Lannoitteiden säästö on arvioitu 30-50\%:ksi (BATEy ja Boyd 1969, Hempler 1973). Näissä kokeissa säästö oli samaa suuruusluokkaa.

Sadon mukulakoko ei muuttunut varsinaisissa syysnostoissa keskimääriin, mutta vuosittain tulos oli erilainen. Sadonlisäys perustui siten joko mukulakoon suurenemiseen tai mukuloiden määrän lisääntymiseen, keskimäärin kuitenkin pääasiassa jälkimmäiseen. Kasvututkimuksen tulokset selvittivät tarkemmin näitä yhteyksiä. Kasvukauden loppupuolella mukuloiden määrä näyttää tasoittuvan kasvuolosuhteiden sallimalle tasolle. Tämän jälkeen lannoitteiden multaus tai sijoitus voi johtaa mukuloiden nopeampaan lisäkasvuun, jolloin voidaan Petterssonin ja Wikströmin (1972) mukaan todeta satokäyrien yhtyminen syyskesällä ja uudelleen eriytyminen myöhemmin syksyllä. Sadon mukulakoon suurenemisen ei tarvitse olla säännöllinen ilmiö, vaan se on mukuloiden määrän lisääntymisen kanssa vaihtoehtoinen sadon nousun muoto. Kumpi vaihtoehto pääsee vallitsemaan johtuu kasvuolosuhteista ja todennäköisesti myös lajikkeen aikaisuudesta (vrt. LARPES 1968, BAERUG 1971).

Lannoitustapa vaikutti tässä kuten muissakin vastaavissa tutkimuksissa sangen vähän tärkkelyspitoisuuteen. Tärkeä ilmiö selostettavassa koesarjassa on se, että sijoittamalla tai multaamalla lannoitteet päästiin suurempaan satoon ilman tärkkelyspitoisuuden alenemista. Lannoituksen määrän lisääminen sen sijaan johti sadon määrän kasvun ohella tärkkelyspitoisuuden alenemiseen. Tämän eron voidaan selittää johtuvan mukulamäärien eroista kummassakin tapauksessa. Pelkkä mukulamäärän lisääntyminen ei kuitenkaan takaa jatkuvaa tärkkelyspitoisuuden korkeana säilymistä, vaan lisäksi tarvitaan myös osittainen lehdistön yhteyttämiskapasiteetin kasvaminen. Tähän viittaavat myös tämän koesarjan tulokset verrattaessa korkean lannoitustason rivimultauksen ja sijoituksen satoja, tärkkelyspitoisuuksia sekä mukuloiden ja versojen määriä keskenään. Tässä tapauksessa rivimultaus johti suurimpaan tärkkelyssadon lisääntymiseen sekä korkean sadon että hyvän tärkkelyspitoisuuden takia. Samalla kasvututkimus osoitti sekä mukulamäärän että versomäärän kasvua.

Lannoitteiden multaaminen riittävään syvyyteen näyttää olevan tehokas keino perunasatojen nostamiseksi ilman ulkoisen ja sisäisen laadun huonone- 
mista. Tämä perustuu nopeampaan kasvun alkamiseen, rehevämpään ja osittain myös tiheämpään varsistoon sekä lisääntyneeseen mukuloiden määrään. Samanaikainen muiden kasvuolojen, lähinnä veden saannin turvaaminen riittävän lannoituksen yhteydessä näyttäisi antavan lisämahdollisuuksia runsaiden hyvänlaatuisten satojen saamiselle ilman ylimääräistä kasvutiheyden muuttamisen tarvetta.

\section{Yhteenveto}

Lannoitteiden rivimultausta ja sijoitusta verrattiin pintalannoitukseen vuosina 1968-72 järjestetyissä kokeissa Hankkijan kasvinjalostuslaitoksella ja Maatalouskoneiden tutkimuslaitoksella. Kokeissa käytettiin kahta lannoitustasoa, 650 ja $1300 \mathrm{~kg} / \mathrm{ha}$ Yklv.

Lannoituksen kaksinkertaistaminen nosti mukulasatoa keskimäärin $12 \%$. Rivimultaus lisäsi satoa $6 \%$ ja sijoitus $11 \%$ pintalannoitukseen verrattuna.

Lannoituksen määrä vaikutti huomattavasti lannoitustavan antamaan tulokseen. Alemmalla lannoitustasolla rivimultaus nosti satoa $7 \%$, sijoitus $18 \%$. Suurempaa lannoitemäärää käytettäessä vastaavat sadonlisäykset olivat molemmissa tapauksissa $5 \%$.

Tärkkelyspitoisuus aleni $0.5 \%$-yksikköä lannoituksen määrää lisättäessä. Lannoitustapa ei vaikuttanut tärkkelyspitoisuuteen merkitsevästi, joskin rivimultaus tuotti hiukan muita korkeampia pitoisuuksia.

Tärkkelyssadot noudattivat mukulasatoja.

Suurten mukuloiden määrä lisääntyi lannoitusta lisättäessä. Lannoitustapa ei vaikuttanut merkitsevästi lajittelutulokseen, joskin selviä eroja vuosittain todettiin.

Lannoituksen lisääminen aiheutti rupisuuden ja seittisten mukuloiden määrän lievän lisääntymisen. Lannoitustapa ei vaikuttanut mukuloiden terveyteen.

Kasvututkimus osoitti lannoitteiden multauksen tai sijoituksen nopeuttavan ja lisäävän perunan vegetatiivista kasvua jopa enemmän kuin lannoituksen määrän kaksinkertaistaminen. Suurempaa lannoitemäärää käytettäessä rivimultaus oli edullisempi kuin sijoitus.

Versojen määrä vaihteli vuosittain $(4.3-5.3)$ huomattavasti enemmän kuin lannoituksen määrästä tai tavasta johtuen. Rivimultaus tuotti suurta lannoitemäärää käytettäessä muita runsaamman versojen määrän.

Mukuloiden määrä kasvia kohti vaihteli runsaasti vuodesta toiseen (8.6 -13.5). Mukuloiden määrä lisääntyi huomattavasti kasvukauden alkupuolella rivimultausta ja varsinkin sijoitusta käytettäessä. Loppukesällä erot pienenivät. 


\section{KIRJALLISUUTTA}

BAERUG, R. 1971. Radgjødsling til seine of tidlige potetsorter. Forsk. Fors. Landbr. 22: 157 -164 .

Batey, T. \& Boyd, D. A. 1969. Placement of fertilizers for potatoes. Phosph. Agric. 54: $27-34$.

Elonen, P., Nieminen, L. \& Kara, O. 1967. Sprinkler irrigation on clay soils in southern Finland. II. Effect on the grain yield of spring cereals. J. Scient. Agric. Soc. Finl. 39: $78-88$.

Hempler, K. 1973. Reihendüngung zu Stärkekartoffeln. Kartoffelbau 24: 68.

LARPES, G. 1968. Rivilannoitus perunallekin. Koetoim. ja Käyt. 25:46-48.

Laughrin, W. M. Production and chemical composition of potatoes related to placement and rate of nitrogen. Amer. Potato J. 48: 1-15.

Nieminen, L., KarA, O. \& Elonen, P. 1967. Kokemuksia sijoituslannoituksesta. Maat. ja Koetoim. 21: 42-49.

Pessi, Y., YLÄNen, M., Leskelä, A \& SyväLAhti, J. 1970. Results of tests made with placement fertilization on the Kotkaniemi Experimental Farm. J. Scient, Agric. Soc. Finl. 42: $193-197$.

Pettersson, A. \& Wiкström, S. 1972. Inledande undersökningar om radmyllning till potatis. Lantbr.högsk. Rapp. Jordbearbetningsavdelning 30:1-27.

SALONEN, M. 1968. Rivilannoitus, sen kehittäminen ja soveltaminen kasvinviljelyyn. Leipä Leveämmäksi 16: $20-22$.

VARIS, E. 1973. The effect of magnesium and potassium on the chemical composition and yield of the potato. Acta Agr. Fenn. 128, 3:3-13. 